\title{
OS NOVOS RUMOS DO EFEITO VINCULANTE NO PROCESSO CIVIL BRASILEIRO E A MITIGAÇÃO DO PRINCÍPIO DO LIVRE CONVENCIMENTO DO JUIZ
}

\section{THE NEW ROUTES OF THE BINDING EFFECT IN THE BRAZILIAN CIVIL PROCESS AND THE MITIGATION OF THE PRINCIPLE OF THE FREE JUDGE CONVINCING}

\section{Letícia Lichs Nascimento Peretto ${ }^{1}$}

RESUMO: É grande hoje a preocupação com a entrega à sociedade de um sistema processual civil que seja eficiente para garantir a realização dos direitos ameaçados de forma isonômica. Na busca de mecanismos aptos a aperfeiçoar o direito processual civil brasileiro, o novo Código de Processo Civil, dentre outros institutos, traz para o direito pátrio o sistema de precedentes com efeito vinculante. $\mathrm{O}$ presente estudo pretende avaliar o impacto que a força vinculante dos precedentes pode causar na valoração das provas pelo magistrado, mais especificamente no princípio do livre convencimento motivado, porquanto, ao que parece, a liberdade do juiz na formação de seu convencimento sofreu mitigação pelo novo sistema processual. $\mathrm{O}$ estudo proposto será levado a efeito tomando como pressuposto o método dedutivo e a pesquisa bibliográfica, com produção descritiva. Serão utilizados como fontes de pesquisa estudos recentes que abordam o problema objeto desta pesquisa.

PALAVRAS-CHAVE: Precedentes. Isonomia. Interpretação. Vinculante. Segurança Jurídica.

ABSTRACT: There is great concern today about the delivery to society of a civil procedural system that is efficient to guarantee the realization of the rights that are threatened in an isonomic way. In the search for mechanisms capable of perfecting Brazilian civil procedural law, the new Code of Civil Procedure, among other institutes, brings into law the system of precedents with binding effect. This study intends to evaluate

1 Especialista em direito processual civil, professora da Universidade do Alto Vale do Rio do Peixe (UNIARP) e servidora pública do Tribunal de Justiça de Santa Catarina. Email: leticialichs@icloud.com. 
the impact that the binding force of the precedents can cause in the evaluation of the evidence by the judge, more specifically in the principle of free convinced reason, because, it seems, the judge's freedom in the formation of his conviction has been mitigated by the new procedural system. The proposed study will be carried out taking as a presupposition the deductive method and the bibliographical research, with descriptive production. Recent researches will be used as sources of research that address the problem object of this research.

KEYWORDS: Precedents. Isonomy. Interpretation. Binding. Legal Safety.

\section{INTRODUÇÃO}

O Brasil passa por um momento de grandes reflexões, não apenas políticas, mas também jurídicas e um dos grandes desafios do Poder Judiciário é dar coerência às decisões judiciais de forma a respeitar e promover o princípio da isonomia. Há tempos o direito brasileiro vem demonstrando preocupação com esse tema e isso se comprova pelas mudanças constitucionais e legais que progressivamente vêm privilegiando alterações que levem em conta a estabilidade do sistema processual.

O presente trabalho tem por objetivo analisar qual o impacto dessas mudanças no princípio do livre convencimento motivado do juiz, considerando que o sistema de precedentes delineado no Código de Processo Civil de 2015, ao que tudo indica, apresenta-se como um limitador à atividade interpretativa judicial.

Para o alcance desse objetivo, buscar-se-á descrever o papel da função jurisdicional e sua transformação ao longo dos tempos, fazendo uma correlação com o princípio da efetividade do processo, a fim de embasar a análise do impacto do sistema de precedentes no princípio do livre convencimento motivado do juiz.

O estudo proposto será levado a efeito tomando como pressuposto o método dedutivo e a pesquisa bibliográfica, com produção descritiva. Serão utilizados como fontes de pesquisa estudos recentes que abordam o problema objeto desta pesquisa. 


\section{A TRANSFORMAÇÃO DA FUNÇÃO JURISDICIONAL}

A separação dos poderes é princípio geral do Direito Constitucional, indispensável para a existência de um Estado Democrático de Direito, cuja origem como doutrina política, consoante bem adverte André Ramos Tavares (2010), é feito de Montesquieu, apesar de os antecedentes de tal teoria terem sido atribuídos às obras de Aristóteles e Locke. (FERREIRA FILHO, 2007).

$\mathrm{Na}$ sua formulação atual, a separação dos poderes corresponde à forma tripartite, que confere a função legislativa - edição de regras gerais, abstratas, impessoais e inovadoras da ordem jurídica - precipuamente ao Poder Legislativo. Ao Executivo cabe, primordialmente, a administração da máquina pública e ao Poder Judiciário, por sua vez, lhe foi incumbida a missão de prestar essencialmente a função jurisdicional, qual seja, a aplicação do direito aos casos concretos, dirimindo conflitos de interesses. (SILVA, J., 2006).

Convém ressaltar que a jurisdição não apenas declara o preceito aplicado ao caso concreto, mas também assegura a prevalência do direito positivo no país, sendo considerada um longa manus da legislação. (CINTRA; GRINOVER; DINAMARCO, 2006).

Essa atividade jurisdicional prestada pelo Estado dá ensejo, então, ao surgimento de uma relação jurídica delineada pelos sujeitos autor, réu e o próprio Estado, que atua por intermédio do juiz, constituindo, assim, o processo (SILVA, O., 2006), meio pelo qual atua a lei, com a finalidade de compor a lide. (SANTOS, 2006).

O processo deve, portanto, se mostrar como um instrumento apto a receber o litígio, atuando na pacificação social e, para tal desiderato, o juiz dele participa representando o interesse 
do Estado - que é secundário - na qualidade de sujeito imparcial da relação processual, devendo permanecer equidistante dos interesses das partes. (ALVIM, 2006).

O Estado desempenha, assim, a função jurisdicional através do processo, substituindo os titulares dos interesses em conflito, outorgando a solução deste de forma imperativa, seja por meio de uma sentença ou através da execução forçada. (CINTRA; GRINOVER; DINAMARCO, 2006).

Não se pode olvidar, porém, da ideia do Estado Social, em que se atribui a este a função fundamental de promover a plena realização dos valores humanos, lugar em que ganha destaque a função jurisdicional pacificadora como causa de eliminação de conflitos. (CINTRA; GRINOVER; DINAMARCO, 2006).

$\mathrm{Na}$ atualidade, portanto, o Poder Judiciário alcançou consciência de que exerce papel de proporção muito mais expressiva do que aquela de mero aplicador do direito, considerando que é o guardião dos direitos fundamentais e que deve, por imposição constitucional, promover a efetivação de tais direitos por meio de uma postura mais ativa, sem que isto seja visto, entretanto, como relativização do princípio da separação dos poderes. (DESTEFENNI, 2012).

A visível falta de comprometimento dos demais Poderes em relação à garantia dos direitos fundamentais, visto que estes não têm sido devidamente promovidos, representa um fator de legitimação à intervenção do Poder Judiciário, demonstrando nítida expansão da jurisdição constitucional. (DESTEFENNI, 2012).

\section{A INAFASTABILIDADE DA JURISDIÇÃO E A EFETIVIDADE DO PROCESSO}

Como é sabido, determinadas pretensões são necessariamente sujeitas à atuação jurisdicional, não cabendo às partes resolvê-las por sua própria força. Lembra Cassio Scarpinella 
Bueno (2015) que a autotutela é vedada e sua contrapartida é a tutela jurisdicional, o que leva à conclusão de que a proteção dos direitos submetidos à jurisdição depende do processo.

Em razão da inafastabilidade da jurisdição, o Estado, quando provocado, não pode se furtar à entrega da solução ao caso concreto como ocorria no direito romano, o qual contava com uma regra conhecida como non liquet, que permitia ao juiz eximir-se do julgamento da causa se entendesse que ela não estava clara ou por não ter encontrado uma solução reputada adequada ao caso. (MARMELSTEIN, 2009).

Tal faculdade não foi absorvida pelo direito brasileiro, uma vez que o Código de Processo Civil de 1973, em seu artigo 126, adverte o julgador da vedação ao non liquet, ou seja, proíbe ao juiz esquivar-se do julgamento da causa com base em lacuna ou obscuridade da lei. No mesmo sentido, a Lei n. 13.105/2015, que instituiu o novo Código de Processo Civil, trouxe idêntica previsão no art. 140, mantendo no ordenamento jurídico brasileiro a vedação à utilização do instituto romano.

É uma consequência também do princípio da plenitude do ordenamento jurídico ou, nas palavras de Rizzatto Nunes (2011, p. 322), completude do sistema jurídico, por ele conceituado como "uma onipresença de normas, regulando todas as ações e comportamentos". Não cabe ao juiz, então, recorrer ao non liquet, pois, considerando o princípio da plenitude do ordenamento jurídico, tem ele o dever de preencher as lacunas e realizar a entrega da prestação jurisdicional, fazendo uso dos mecanismos de integração do direito, quais sejam, a analogia, os costumes e os princípios gerais do direito, estampados no art. $4^{\circ}$ da Lei de Introdução às Normas do Direito Brasileiro.

Porém, não se pretende a outorga de qualquer resposta. Hodiernamente é possível constatar no mundo jurídico a intensa a preocupação com a efetividade da prestação jurisdicional que, 
segundo Marcos Destefenni (2012, p. 215), “[...] somente será atingida quando o processo puder satisfazer o titular de um direito de maneira rápida e satisfatória".

O princípio da efetividade ganhou destaque constitucional com sua inserção no art. $5^{\circ}, \mathrm{XXXV}$, da Constituição da República e entende-se concretizado quando os mecanismos processuais são aptos a propiciar aos jurisdicionados decisões justas, úteis e tempestivas. (WAMBIER; TALAMINI, 2012).

Assim, a efetividade está relacionada à adequada tutela jurisdicional ao direito material, por meio de instrumentos hábeis e adequados às especificidades do caso concreto. Nas palavras de Luiz Guilherme Marinoni e Sérgio Cruz Arenhart (2006, p. 61), o destinatário do serviço jurisdicional "[...] não desejava outra coisa senão um processo que fosse capaz de conferir ao cidadão o mesmo resultado que alcançaria caso o agir (a ação) privado (de direito material) não estivesse proibido pelo Estado".

Ao encontro dessa tendência, o novo Código de Processo Civil demonstrou atenção à adequada tutela jurisdicional, buscando sua prestação dentro de um processo justo, efetivo e tempestivo, de forma a outorgar unidade ao sistema jurídico. (MARINONI; ARENHART; MITIDIERO, 2015).

\section{PRINCÍPIO DA PERSUASÃO RACIONAL E A OBRIGATORIEDADE DA MOTIVAÇÃO DAS DECISÕES JUDICIAIS}

Uma das adversidades por vezes encontrada pelo julgador na realização da atividade jurisdicional é a falta de elementos sobre o caso concreto, porquanto não é tão incomum que ele se depare com duas ou até mesmo mais versões completamente distintas para os mesmos fatos. No entanto, essa dificuldade é atenuada com a atividade probatória realizada pelas partes. 
Isso em razão de que o direito brasileiro estabelece regras acerca do ônus da prova, incumbindo cada uma das partes da responsabilidade de fazer prova de suas alegações, com o objetivo de influenciar o julgador na formação do convencimento dele sobre os fatos que envolvem a causa. (BURGARELLI, 2000). Assim, como destinatário delas, deve o juiz valer-se das provas produzidas nos autos e dos mecanismos de integração do direito para entregar a prestação jurisdicional, proferindo a decisão ao caso concreto.

Dentre os sistemas probatórios existentes, o Brasil adotou o da persuasão racional ou livre convencimento motivado - um meio-termo entre o sistema da livre convicção e o da tarifação das provas - através do qual o juiz é livre para formar sua convicção, desde que indique os motivos de seu convencimento. (DESTEFENNI, 2012).

Tal princípio se contrapõe ao sistema de tarifação, no qual cada prova traz em si um valor previamente definido pela lei. Também não se confunde com o princípio do livre convencimento, uma vez que a liberdade da avaliação do juiz não é plena; encontra limite na fundamentação da sua conclusão, característica não presente no sistema do livre convencimento. (PINHO, 2012).

O direito brasileiro, quando adotou o princípio do livre convencimento motivado, optou por conferir ao magistrado, então, certa liberdade na apreciação dos elementos e das provas produzidas nos autos, permitindo que ele avalie livremente a prova elaborada pelas partes, retirando dela, sem limitações técnicas, o seu convencimento. (SILVA, O., 2006).

O sistema da persuasão racional demonstra não só a evolução dos sistemas de apreciação das provas, mas se apresenta como uma forte garantia de correta distribuição da justiça, considerando que o poder de o juiz apreciar livremente a prova 
produzida nos autos deve ser exercido de forma fundamentada, a fim de evitar que todas as demais garantias restem enfraquecidas, o que certamente ocorreria se a decisão pudesse se despojar da motivação. O juiz, então, está vinculado à lei e ao sistema de garantias institucionalizado, a que todos devem observância, não podendo se furtar a ele. (GRECO FILHO, 2009).

Convém ressaltar que o legislador quando da elaboração do novo Código de Processo Civil, elencou esse preceito no art. 371, porém, de forma redimensionada, porquanto, como advertem Fredie Didier e outros (2015), o novo diploma processual não utiliza mais o advérbio "livremente" ao se referir à apreciação da prova, considerando que a valoração dela não é mais dotada de liberdade. Sustentam, ademais, que "o convencimento do julgador deve ser racionalmente motivado: isso é quanto basta para a definição do sistema de valoração da prova pelo juiz adotado pelo CPC-2015." (2015, p. 102).

Nessa órbita, o novo Código de Processo Civil, no $\S 1^{\circ}$ do art. 489, ao abordar a fundamentação das decisões judiciais, operando por exclusão, elencou um inovador rol de hipóteses em que considera uma decisão não fundamentada, in verbis:

$\S 1^{\circ}$ Não se considera fundamentada qualquer decisão judicial, seja ela interlocutória, sentença ou acórdão, que:

I - se limitar à indicação, à reprodução ou à paráfrase de ato normativo, sem explicar sua relação com a causa ou a questão decidida;

II - empregar conceitos jurídicos indeterminados, sem explicar o motivo concreto de sua incidência no caso;

III - invocar motivos que se prestariam a justificar qualquer outra decisão;

IV - não enfrentar todos os argumentos deduzidos no processo capazes de, em tese, infirmar a conclusão adotada pelo julgador; 
V - se limitar a invocar precedente ou enunciado de súmula, sem identificar seus fundamentos determinantes nem demonstrar que o caso sob julgamento se ajusta àqueles fundamentos;

VI - deixar de seguir enunciado de súmula, jurisprudência ou precedente invocado pela parte, sem demonstrar a existência de distinção no caso em julgamento ou a superação do entendimento. (BRASIL, 2015).

Assim, forçoso concluir que as decisões judiciais estão submetidas a certo controle da intersubjetividade, considerando a exigência de que a fundamentação seja completa, estruturada e, principalmente, relacionada ao caso concreto, ou seja, não se pode esquivar à completa análise dos argumentos relevantes apresentados pelas partes, evidenciando, assim, a racionalidade das opções interpretativas. (MARINONI; ARENHART; MITIDIERO, 2015).

Longe, todavia, de querer aqui afirmar-se que a nova previsão legal - a qual certamente objetiva à concretização da regra contida no artigo 93, IX, da Constituição da República - seja a solução à problemática apontada por Lênio Streck (2015) na criticada discricionariedade que permeia as decisões judiciais, cujo tema este estudo sequer tem a pretensão de debater.

No entanto, não se pode desconsiderar que a nova regra, aliada ao dever de indicar os critérios de ponderação que foram empregados na solução de eventual conflito entre normas jurídicas, imposto no $\S 2^{\circ}$ do mesmo dispositivo, demonstra uma notável redução na margem de discricionariedade do magistrado, na formulação da decisão de entrega da prestação jurisdicional.

O mesmo pode ser constatado quando da análise da vedação acima citada à simples invocação de termos ou conceitos indeterminados ou vagos, sem demonstrar seu cabimento ao caso concreto, pois a ausência deste raciocínio de pertinência acarreta não somente a falta de fundamentação, mas principal- 
mente a inobservância do texto constitucional, cujos parâmetros devem ser observados por todos os ramos do direito.

Até aqui, entretanto, não se vislumbra alteração substancial no Processo Civil a ponto de interferir consideravelmente nas características do princípio do livre convencimento motivado, a não ser um maior rigor quanto aos aspectos da fundamentação, sendo possível constatar que o juiz continua livre para decidir, desde que apoie sua decisão nas provas produzidas nos autos e a motive devidamente.

\section{O NOVO PAPEL DOS TRIBUNAIS SUPERIORES}

Hodiernamente, muito se tem discutido acerca da necessidade de concretização da justiça e da efetividade do processo. Se a jurisdição é inafastável para a solução dos conflitos, porquanto, como dito alhures, a autotutela, em regra, não é admitida, o Estado, no exercício da função jurisdicional, deve primar pela segurança jurídica, valor fundamental a um Estado Democrático de Direito, fator que exige garantia de estabilidade do sistema e previsibilidade das decisões judiciais.

A segurança jurídica não pode ser entendida apenas como um princípio que assegura o respeito a situações consolidadas no passado, mas também deve garantir as legítimas expectativas surgidas e um modelo seguro de conduta presente, de forma que o jurisdicionado saiba de antemão que a conduta por ele adotada com base em jurisprudência consolidada não será abruptamente interpretada de forma diversa. (DIDIER; BRAGA; OLIVEIRA, 2015).

$\mathrm{Na}$ mesma vertente, defende-se a ideia de que para o alcance da tão sonhada efetividade da prestação jurisdicional, cuja morosidade é inegável, é necessário desafogar o Poder Judiciário, encerrado por uma infinidade de demandas muitas 
vezes repetidas, mediante a implementação de mecanismos que garantam a celeridade processual.

$\mathrm{Na}$ tentativa de superar tais adversidades, tem-se entendido que o Supremo Tribunal Federal e o Superior Tribunal de Justiça não devem funcionar na condição de mais uma instância ordinária, devendo atuar apenas quando a causa transcender ao mero interesse particular das partes, expressando a última palavra em matéria constitucional ou federal, a fim de unificar o entendimento sobre o assunto. (RODOVALHO, 2015).

Seguindo essa diretriz, uma nova função dos Tribunais Superiores pode ser vislumbrada a partir do novo Código de Processo Civil, principalmente no que tange ao recurso especial e extraordinário, pois os Tribunais Superiores passam a ser caracterizados como cortes de interpretação e de precedentes, e não mais apenas como simples juízos de controle e de jurisprudência. (MARINONI; ARENHART; MITIDIERO, 2015).

Nas palavras de Fredie Didier e outros (2015, p. 441), precedente é conceituado como "A decisão judicial tomada à luz de um caso concreto, cujo núcleo essencial pode servir como diretriz para o julgamento posterior de casos análogos"

Marinoni e outros destacam a importância de distinguir as funções exercidas pelas Cortes Superiores, a fim de bem operar o sistema de precedentes. Segundo eles, as Cortes de Justiça (Tribunais de Justiça e Tribunais Regionais Federais) possuem a função de "[...] controlar a interpretação dos fatos da causa, da prova produzida e do direito aplicável ao caso concreto e fomentar o debate a respeito das possíveis soluções interpretativas por meio da jurisprudência." (2015, p. 869). Já às Cortes Supremas (Supremo Tribunal Federal e Superior Tribunal de Justiça) cabe a importante função de interpretar o direito e atribuir a ele unidade, conferindo a última palavra acerca de como deve ser entendido e interpretado. 
Tal evolução, no entanto, não pode ser atribuída apenas ao processo civil. A alteração no perfil do recurso extraordinário e especial também é decorrência da evolução da teoria da interpretação, a partir do momento em que se compreende que a norma jurídica é o resultado e não o objeto da interpretação. Assim, o julgamento de um Recurso Especial ou Extraordinário acaba por conferir aos Tribunais Superiores uma oportunidade para a outorga da adequada interpretação ao direito. (MARINONI; ARENHART; MITIDIERO, 2015).

\section{O EFEITO VINCULANTE E A FORMAÇÃO DE DECISÕES PARADIGMÁTICAS}

Aliada a alteração do perfil dos Recursos Extraordinários, uma nova previsão legislativa promete alterar os rumos do processo civil brasileiro, que é a expansão da força vinculante das decisões das Cortes Superiores e dos próprios Tribunais de Justiça, prevista no art. 927 do novo diploma processual civil.

Ainda em 1993, alertavam Gilmar Mendes e Ives Gandra da Silva Martins que o efeito vinculante das decisões das Cortes Superiores sobre atos das instâncias inferiores não era novidade, considerando que este sistema já era adotado em vários países, a exemplo de Portugal, Argentina e México.

Muito embora a discussão acerca do efeito vinculante das decisões judiciais tenha angariado força no direito brasileiro com a iminência da entrada em vigor do novo Código de Processo Civil, convém ressaltar que tal efeito não é inédito no ordenamento jurídico nacional, pois traços dele podem ser encontrados desde há muito tempo, a exemplo do instituto que trata da jurisprudência dominante, incluído no ano de 1998 no art. 557 do Código de Processo Civil de 1973, bem como no da súmula impeditiva de recurso, prevista no mesmo diploma legal desde $2006\left(\right.$ art. 518, $\left.\S 1^{\circ}\right)$. 
Ademais, desde o ano de 2004, por força da Emenda Constitucional n. 45, há previsão de edição de súmula de efeito vinculante pelo Supremo Tribunal Federal, cujo objetivo está previsto no $\S 1^{\circ}$ do art. 103-A da Constituição da República, que pela importância transcreve-se abaixo:

$\S 1^{\circ}$ A súmula terá por objetivo a validade, a interpretação e a eficácia de normas determinadas, acerca das quais haja controvérsia atual entre órgãos judiciários ou entre esses e a administração pública que acarrete grave insegurança jurídica e relevante multiplicação de processos sobre questão idêntica. (BRASIL, 1988).

As súmulas vinculantes nascem a partir de um caso concreto e tal fato as aproxima do stare decisis, instituto típico do sistema common law, no qual o precedente possui força normativa que exige não somente observância interna, pelo próprio tribunal, como externa, pelos demais órgãos do Poder Judiciário e da Administração Pública. É o chamado efeito vinculante (bindig effect). (NOVELINO, 2013).

Adverte Paulo Hamilton Siqueira Jr. (2011) que o direito pátrio filia-se ao sistema jurídico romanístico, no qual as súmulas não possuem efeito vinculante. No entanto, ao inserir no ordenamento jurídico um instituto que vincula os órgãos inferiores às decisões dos superiores, vislumbra-se uma nítida influência do sistema common law (anglo-saxônico).

Muito se discutiu acerca das desvantagens e dos benefícios de se estabelecer no ordenamento jurídico brasileiro instituto de tamanha força vinculante. Não obstante, a par de controvérsias, Lênio Streck (2008, p. 173), autoconceituado como crítico das súmulas vinculantes, acredita que "elas podem ser importantes para colocar o 'selo jurídico' em conquistas hermenêuticas," vindo ao encontro do papel de conferir unidade ao direito atribuído ao Supremo Tribunal Federal.

A implementação de um sistema de precedentes pelo novo 
Código de Processo Civil é muito significativa e por meio dele o juiz deixará de pensar na decisão apenas no aspecto endoprocessual e passará a vislumbrá-la para além do processo, percebendo que ela pode, inclusive, transmudar-se em regra geral, ou seja, em um precedente (NOGUEIRA, 2014).

Sobre o sistema de precedentes, tem-se a valiosa contribuição de Rudson Marcos (2017, p. 24):

Os objetivos principais na adoção de um sistema de Precedentes Judiciais são, especialmente, a agilização e a simplificação do sistema processual. Também propicia maior segurança jurídica, por meio de decisões judiciais tanto mais previsíveis quanto determinadas, em seu objeto. Além disso, dota-se de concretude o princípio da isonomia, ao ensejar que situações fáticas e juridicamente idênticas possam ter respostas judiciais semelhantes, coerentes e íntegras.

Cássio Scarpinella Bueno (2015) sustenta, entretanto, que o direito brasileiro não tem tradição de common law, mas sim, busca a solução ao caso concreto de forma alheia a qualquer teoria de precedentes, baseado em uma análise crítica de diversos fatores. Defende a possibilidade de aplicação de efeito vinculante somente nas hipóteses constitucionalmente autorizadas, ou seja, não vislumbra na Constituição da República autorização para que o legislador infraconstitucional atribua tal efeito às decisões jurisdicionais dos Tribunais Superiores.

Entende, ainda, que o vocábulo precedente, empregado no $\S^{\circ} 2$ do art. 927, não se refere aos precedentes típicos do sistema commom law e, por tal motivo, deve ser interpretado no sentido de impor que os enunciados de súmulas "[...] guardem correspondência ao que foi efetivamente julgado nos casos concretos que lhe deram origem." (2015, p. 544).

Prossegue afirmando que as novas disposições legais representam apenas uma aposta do legislador infraconstitucional na redução do número de litígios e no aumento da previsibilidade 
das decisões judiciais, conferindo ao sistema maior segurança jurídica e isonomia, com base na observância das decisões proferidas pelos Tribunais Superiores, Tribunais de Justiça e Tribunais Regionais Federais pelos demais órgãos jurisdicionais.

Nesse sentido, Lênio Streck e Luiz Abboud (2017) tecem uma crítica ao que parte da doutrina chama de sistema de precedentes, instituído pelo Código de Processo Civil, afirmando não se tratar de um sistema propriamente dito, em razão de que ele, originariamente, não permite uma aplicação mecânica ou subsuntiva, ou seja, depende de interpretação. Sustentam que o novo diploma processual civil brasileiro, na verdade, criou provimentos judiciais vinculantes, "cuja função é reduzir a complexidade judicial para enfrentar o fenômeno brasileiro da litigiosidade repetitiva" e concluem que o art. 927 não pode ser equiparado a um sistema de precedentes, sob pena de acarretar uma aplicação desvirtuada do Código.

No entanto, a partir do momento em que o Superior Tribunal de Justiça ou o Supremo Tribunal Federal atribuem à regra determinada interpretação, constitui grave infidelidade ao direito deixar de aplicá-la. Daí a função de conferir unidade ao direito e não a de uniformizá-lo, repetindo por diversas vezes a mesma solução jurídica diante da multiplicidade de casos concretos. (MARINONI; ARENHART; MITIDIERO, 2015).

Fredie Didier e outros $(2015$, p. 468) salientam que não é possível entender como isonômica a postura de um órgão do Estado que "[...] diante de uma situação concreta, chega a um determinado resultado e, diante de outra situação concreta, em tudo semelhante à primeira, chega à solução distinta".

Não é forçoso lembrar que a Constituição, dotada de supremacia formal e material, cuja força normativa não mais de discute, opera não apenas como parâmetro de validade da ordem jurídica, mas como veículo de interpretação de todas as 
normas do ordenamento. (BARROSO, 2011).

\section{A EXPANSÃO DO EFEITO VINCULANTE NO ORDENAMENTO JURÍDICO BRASILEIRO E A MITIGAÇÃO DO PRINCÍPIO DO LIVRE CONVENCIMENTO DO JUIZ}

Para o desiderato a que se propõe o presente trabalho, serão deixadas de lado quaisquer discussões acerca da (in)constitucionalidade dos novos dispositivos processuais acima elencados, a fim de concentrar o estudo no impacto do efeito vinculante sobre o princípio do livre convencimento motivado.

Embora o novo Código de Processo Civil não utilize no art. 927 o vocábulo "vinculante", a interpretação de tal dispositivo permite inferir a intenção do legislador em vincular os juízes e Tribunais à interpretação conferida pelas Cortes Superiores e aos Tribunais a que estão sujeitos, uma vez que exige deles a observância desta (BUENO, 2015), conforme se pode constatar a partir da leitura do texto abaixo transcrito:

Art. 927. Os juízes e os tribunais observarão:

I - as decisões do Supremo Tribunal Federal em controle concentrado de constitucionalidade;

II - os enunciados de súmula vinculante;

III - os acórdãos em incidente de assunção de competência ou de resolução de demandas repetitivas e em julgamento de recursos extraordinário e especial repetitivos;

IV - os enunciados das súmulas do Supremo Tribunal Federal em matéria constitucional e do Superior Tribunal de Justiça em matéria infraconstitucional;

$\mathrm{V}$ - a orientação do plenário ou do órgão especial aos quais estiverem vinculados.

$\S 1^{\circ}$ Os juízes e os tribunais observarão o disposto no art. 10 e no art. $489, \S 1^{\circ}$, quando decidirem com fundamento 
neste artigo.

$\S 2^{\circ} \mathrm{A}$ alteração de tese jurídica adotada em enunciado de súmula ou em julgamento de casos repetitivos poderá ser precedida de audiências públicas e da participação de pessoas, órgãos ou entidades que possam contribuir para a rediscussão da tese.

$\S 3^{\circ} \mathrm{Na}$ hipótese de alteração de jurisprudência dominante do Supremo Tribunal Federal e dos tribunais superiores ou daquela oriunda de julgamento de casos repetitivos, pode haver modulação dos efeitos da alteração no interesse social e no da segurança jurídica.

$\S 4^{\circ} \mathrm{A}$ modificação de enunciado de súmula, de jurisprudência pacificada ou de tese adotada em julgamento de casos repetitivos observará a necessidade de fundamentação adequada e específica, considerando os princípios da segurança jurídica, da proteção da confiança e da isonomia.

$\S 5^{\circ}$ Os tribunais darão publicidade a seus precedentes, organizando-os por questão jurídica decidida e divulgando-os, preferencialmente, na rede mundial de computadores. (BRASIL, 2015).

A expressão "observarão" demonstra a força imperativa do vocábulo, de forma a não restar dúvida de que, havendo precedente sobre a questão sub judice, não é permitido ao juiz escolher outra opção interpretativa, pois não se trata de uma faculdade e sim de imperatividade. (DONIZETE, 2015).

A partir desse raciocínio, é inevitável concluir que o novo direito processual civil criou um limitador ao princípio do livre convencimento motivado, não bastando mais somente ao magistrado fundamentar suas decisões nas provas produzidas nos autos. A ideia de total independência jurídica do juiz no sentido de que, no exercício de suas funções, o julgador é o intérprete da lei, não subordinado à interpretação de qualquer outro órgão jurisdicional, mas tão somente à lei, defendida por Moacir Amaral Santos (2008), não encontra mais fundamento 
na atual sistemática do processo civil.

Defende Elpídio Donizette (2015, p. 697), no entanto, que a nova disposição processual não afasta a independência dos juízes e nem os distancia do princípio do livre convencimento motivado, por entender que "[...] ontologicamente não há diferença entre a aplicação da lei ou do precedente, a não ser pelo fato de que, de regra, este contém mais elementos de concretude do que aquela".

Ouso a discordar de tal entendimento porquanto, conforme esclarecido acima, o vocábulo livre foi extirpado do novo Código de Processo Civil no que tange ao sistema de provas. Ademais, o precedente somente surge após a realização de atividade interpretativa sobre o texto da lei e é o resultado dessa operação que vinculará os demais órgãos do Poder Judiciário. Não se pode olvidar que o Poder Judiciário é uma instância representativa não eleita, de forma que suas decisões, ainda que paradigmáticas e vinculantes, não podem ser igualadas ao regular processo legislativo.

Traz o novo Código de Processo Civil, portanto, um filtro hermenêutico para as decisões judiciais. Ao juiz ainda cabe apreciar os fatos e as provas produzidas no processo. No entanto, embora se convença que a solução X é a mais adequada ao caso concreto e tenha fundamentos para sustentar tal posicionamento, não poderá assim decidir se os Tribunais Superiores ou o Tribunal de Justiça a que estiver vinculado tiverem atribuído à regra interpretação diversa.

Não se pode olvidar que o efeito vinculante não retira do magistrado a realização do juízo sobre a causa, a ponto de identificar as particularidades do caso concreto. Convencendose o juiz de que não é caso de aplicação do precedente, poderá afastá-lo, obviamente, de forma fundamentada.

Ademais, a aplicação de um precedente em uma situação 
que não permitiria a sua utilização é também violadora do princípio da igualdade, porquanto acarretará tratamento igual em situações que são concretamente distintas. (DIDIER; BRAGA; OLIVEIRA, 2015).

Os precedentes, posto que tenham a função de reduzir enganos inerentes ao discurso das fontes legislativas, não dispensam interpretação do significado da linguagem empregada e do âmbito de aplicação, ou seja, não se pode trabalhar com eles sem individualizar suas origens e significados, e sem relacioná-los com as particularidades do caso concreto. (MARINONI; ARENHART; MITIDIERO, 2015).

No entanto, a nova sistemática processual pretende que, uma vez constatada a identidade entre o caso concreto e o que ensejou a prolação da decisão paradigmática, seja esta observada de forma compulsória, demonstrando, assim, que o princípio do livre convencimento motivado já não é mais pleno na atual sistemática processual brasileira.

\section{CONCLUSÃO}

O presente estudo não pretendeu, em absoluto, apontar a mitigação do princípio do livre convencimento como um aspecto negativo do sistema de precedentes, uma vez que é inegável que este trará segurança jurídica tanto aos operadores do direito quanto aos jurisdicionados, permitindo o fomento do princípio da isonomia, um dos ideais perseguidos pelo direito.

Parte-se, portanto, da premissa de que a lei é igual para todos e, se é assim, torna-se indispensável que ela seja aplicada de forma uníssona para os casos assemelhados. A velha máxima que enuncia que "cada juiz é uma sentença" não encontra espaço dentro do princípio da isonomia, em sua atual dimensão. No entanto, as diversas interpretações acerca do mesmo dispositivo legal acabam por permitir sua aplicação de forma 
dissímil em casos muito semelhantes, ou até mesmo idênticos, causando enorme insegurança jurídica para os jurisdicionados e para os operadores do direito.

Convém salientar que, por força do art. $3^{\circ}$ da Lei de Introdução às Normas do Direito Brasileiro, a ninguém é dado escusar-se do cumprimento da lei alegando seu desconhecimento, ainda que impossível a apreensão de todas as regras previstas no ordenamento jurídico, até mesmo porque o sistema é muito dinâmico, considerando que o direito deve acompanhar a evolução da sociedade para cumprir efetivamente seu papel de regular a vida em sociedade. Não obstante, conhecer a letra da lei nos tempos de hoje, com tamanho avanço dos meios de comunicação, já não é tarefa das mais árduas.

Operação que ganhou maior complexidade, no entanto, é a de desvendar a norma que será extraída do texto legal pelo seu intérprete. O jurisdicionado pode até conhecer o texto que compõe a regra, mas muitas vezes fica inviável antever qual a interpretação que será adotada pelo julgador para aquele dispositivo, diante da diversidade de entendimentos e interpretações acerca do assunto.

É essa celeuma que o efeito vinculante busca evitar ou ao menos minimizar. A vinculação dos Tribunais às decisões proferidas pelas Cortes Superiores visa conferir maior autoridade a estas, considerando esse novo papel de dar a última e concludente - mas não imutável - interpretação ao direito. A mesma autoridade pretende-se conferir às decisões dos Tribunais em relação aos seus juízes, porém, em menor proporção territorial e tal sistemática impõe uma reflexão no que tange à nova dimensão do princípio do livre convencimento motivado.

\section{REFERÊNCIAS}

ALVIM, José Eduardo Carreira. Teoria geral do processo. 11. ed. Rio de Janeiro: Forense, 2006. 
BARROSO, Luiz Roberto. Curso de direito constitucional contemporâneo. 3. ed. São Paulo: Saraiva, 2011.

BRASIL. Constituição da República Federativa do Brasil, de 5 de outubro de 1988. Disponível em: $<$ http://www.planalto.gov.br/ccivil_03/constituicao/constituicaocompilado.htm>. Acesso em: 6 out. 2016.

BRASIL. Decreto-lei n. 4657, de 4 de setembro de 1942. Disponível em: <http://www. planalto.gov.br/ccivil_03/decreto-lei/Del4657compilado.htm>. Acesso em: 20 set. 2015.

BRASIL. Lei n. 13.105, de 16 de março de 2015. Disponível em: <http://www.planalto.gov.br/ccivil_03/_ato2015-2018/2015/lei/113105.htm>. Acesso em: 18 set. 2016.

BUENO, Cassio Scarpinella. Manual de direito processual civil. São Paulo: Saraiva, 2015.

BURGARELLI, Aclibes. Tratado das provas civeis. São Paulo: Juarez de Oliveira, 2000.

CINTRA, Antonio Carlos de Araújo; GRINOVER, Ada Pellegrini; DINAMARCO, Cândido Rangel. Teoria geral do processo. 22. ed. Malheiros. 2006.

DESTEFENNI, Marcos. Manual de processo civil individual e coletivo. São Paulo: Saraiva, 2012.

DIDIER JR. Fredie; BRAGA, Paula Sarno; OLIVEIRA, Rafael Alexandria. Curso de direito processual civil. 10. ed. Salvador: Juspodivm, 2015. 4 v.

DONIZETTI, Elpídio. Novo código de processo civil comentado. São Paulo: Atlas, 2015.

FERREIRA FILHO, Manoel Gonçalves. Curso de direito constitucional. 33. ed. São Paulo: Saraiva, 2007.

GRECO FILHO, Vicente. Direito processual civil brasileiro. 21. ed. São Paulo: Saraiva, 2009. $1 \mathrm{v}$.

MARCOS, Rudson. Ensaio para uma análise dos precedentes judiciais nos conflitos socioambientais, frente a teoria do Estado e da Constituição. Revista Da Esmesc, Florianópolis, v. 24, n. 30, 2017. Disponível em: <https://revista.esmesc.org.br/re/article/ view/159/133>. Acesso em: 16 maio 2018.

MARINONI, Luiz Guilherme; ARENHART, Sérgio Cruz; MITIDIERO, Daniel. Novo código de processo civil comentado. São Paulo: Revista dos Tribunais, 2015.

MARINONI, Luiz Guilherme; ARENHART, Sérgio Cruz. Manual do processo de conhecimento. 5. ed. São Paulo: Revista dos Tribunais, 2006.

MARMELSTEIN, George. O asno de buridano, o non liquet e as katchangas. Disponível em: <http://direitosfundamentais.net/2009/01/07/o-asno-de-buridano-o-non-liquet-e-as-katchangas/>. Acesso em: 9 out. 2015.

MARTIS, Ives Gandra da Silva; MENDES, Gilmar Ferreira. Da eficácia das decisões do Supremo Tribunal Federal. Cadernos de direito tributário e finanças públicas. Ano 1. n. 2. Revista dos Tribunais, 1993. Disponível em: <file://C:/Users/Let\%C3\%ADcia/ Downloads/da $\% 20$ eficacia $\% 20$ das $\% 20$ decises $\% 20$ do $\% 20$ supremo $\% 20$ tribunal $\% 20$ 
federal.pdf>. Acesso em: 28 set. 2015.

NOGUEIRA, Cláudia Albagli. O novo código de processo civil e o sistema de precedentes judiciais: pensando em um paradigma discursivo da decisão judicial. Disponível em: < http://www.editoraforum.com.br/ef/index.php/sem-categoria/o-novo-codigode-processo-civil-e-o-sistema-de-precedentes-judiciais-pensando-um-paradigmadiscursivo-da-decisao-judicial-2/. Acesso em: 3 set. 2015.

NOVELINO, Marcelo. Manual de direito constitucional. 8. ed. São Paulo: Método, 2013.

NUNES, Rizzatto. Manual de introdução ao estudo do direito. 10. ed. São Paulo: Saraiva, 2011.

PINHO, Humberto Dalla Bernardina de. Direito processual civil contemporâneo. 4. ed. São Paulo: Saraiva, 2012. 1 v.

RODOVALHO, Thiago. Novo CPC doutrina selecionada: processos nos tribunais e meios de impugnação às decisões judiciais. coordenador geral, Fredie Didier Jr.; organizadores, Lucas Buril de Macêdo, Ravi Peixoto, Alexandre Freire. Salvador: Juspodivum, 2015. $6 \mathrm{v}$.

SANTOS, Moacir Amaral. Primeiras linhas de direito processual civil. 25. ed. São Paulo: Saraiva, 2008. $1 \mathrm{v}$.

SILVA, José Afonso da. Curso de direito constitucional positivo. São Paulo: Malheiros, 2006 .

SILVA, Ovídio A. Baptista; GOMES, Fábio Luiz. Teoria geral do processo civil. 4. ed. São Paulo: Revista dos Tribunais. 2006.

SIQUEIRA JR., Paulo Hamilton. Direito processual constitucional. 5. ed. São Paulo: Saraiva, 2011.

STRECK, Lênio Luiz; ABBOUD, Georges. O que é isso - o sistema (sic) de precedentes no CPC. Disponível em: <http://www.conjur.com.br/2016-ago-18/senso-incomumisto-sistema-sic-precedentes-cpc $>$. Acesso em: 23 set. 2017.

STRECK, Lênio Luiz. Hermenêutica e interpretação. Disponível em: <http://www6. univali.br/seer/index.php/\%20nej/article/viewFile/2308/1623>. Acesso em: 27 set. 2015.

STRECK, Lênio Luiz. Súmulas, vagueza e ambigüidades: necessitamos de uma teoria geral de precedentes? In: Direitos fundamentais e justiça. n. 5, 2008. Disponível em: <http://www.dfj.inf.br/Arquivos/PDF_Livre/5_Doutrina_7.pdf, p. 173>. Acesso em: 30 set. 2015 .

TAVARES, André Ramos. Curso de direito constitucional. 8. ed. São Paulo: Saraiva, 2010 .

WAMBIER, Luiz Rodrigues; TALAMINI, Eduardo. Curso avançado de processo civil. 12. ed. São Paulo: Revista dos Tribunais, 2012.

Recebido em: 30/05/2018

Aprovado em: 13/07/2018 